\title{
Conservation genetics of otters: Review about the use of non- invasive samples
}

\author{
Sandra L. Aristizábal Duque ${ }^{1 *}$, Luz Y. Orozco-Jiménez ${ }^{1}$, Carolina Zapata-Escobar ${ }^{1}$ and Jaime A. Palacio-Baena ${ }^{1}$ \\ ${ }^{1}$ Grupo de Investigación en Gestión y Modelamiento Ambiental-GAIA, Facultad de Ingeniería, Universidad de Antioquia. Cra 53 \\ No 61-30, Lab 230, Medellín. Antioquia, 0500034, Colombia. E-mail: sandra liliana26@yahoo.es (SLAD), lyorozcoj@gmail.com \\ (LYOJ), caroze30@yahoo.com (CZE), jpalaciob@gmail.com (JAPB). \\ *Corresponding author
}

Wild population management programs require determining some fundamental aspects for conservation, including population structure, flow between populations, evolutionary history and kinship, among others. Since sample collection from wild mammals for DNA extraction is a complex task, conservation genetics has developed non-invasive sampling techniques, which allow obtaining DNA without the need to capture individuals. For the genetic characterization of otter populations, stools are frequently used as source of DNA for amplification of molecular markers (microsatellites, mitochondrial segments and sequences for determining sex) in studies on genetic diversity, phylogeography, population structure and size, among others. This review summarizes the application of non-invasive sampling techniques in genetic studies of otter species. Genetic characterization studies that use stools as source of DNA support the usefulness of this material to get amplified markers in the genotyping of individuals. They also suggest the use of fresh samples and appropriate conservation methods to avoid DNA degradation, as well as quantify the potential errors in genotyping, such as false and null alleles.

En los programas de manejo de poblaciones silvestres es necesario conocer algunos aspectos fundamentales para su conservación como la estructura poblacional, el flujo entre poblaciones, la historia evolutiva y el parentesco, entre otros. Dado que en mamíferos silvestres es difícil acceder a muestras para la extracción de ADN, la genética de la conservación ha desarrollado técnicas de muestreo no invasivas, que permiten obtener ADN sin necesidad de capturar los individuos. En la caracterización genética de poblaciones de nutrias se emplean frecuentemente las heces como fuente de ADN para la amplificación de marcadores moleculares (microsatélites, segmentos mitocondriales y secuencias para la determinación del sexo) en estudios de diversidad genética, filogeografía, estructura y tamaño de las poblaciones, entre otros. En ésta revisión se presenta una síntesis de la aplicación de técnicas de muestreo no invasivas en los estudios genéticos de las especies de nutria. Los estudios de caracterización genética, utilizando heces como fuente de ADN, coinciden en la utilidad de este material para obtener amplificados de calidad en la genotipificación de individuos. También sugieren el uso de muestras frescas y la aplicación de métodos de conservación apropiados para evitar la degradación del ADN y cuantificar los posibles errores de genotipificación como los alelos falsos y nulos. ADN mitocondrial, diversidad genética, microsatélites, marcadores moleculares, muestreos no invasivos, nutrias.

Key words: genetic diversity; microsatellites; mitochondrial DNA; molecular markers; non-invasive sampling: otters.

(C) 2018 Asociación Mexicana de Mastozoología, www.mastozoologiamexicana.org

\section{Introduction}

Conservation Genetics studies the factors that affect the genetic diversity and the current distribution of species, with the aims of reducing the probability of extinction and preserving biodiversity. Genetic diversity is the raw material for evolution, because it favors the adaptation and speciation of organisms (Hedrick 2001). Knowledge of the genetic diversity of a species allows determining the effect of habitat fragmentation on the reduction of gene flow, inbreeding, and the ability to evolve in response to environmental changes, as well as defining evolutionarily relevant units (Frankham et al. 2002; Moritz 2002). The articulation of this information with the ecological characteristics of populations contributes to the definition of appropriate management strategies, as conservation seeks to maintain biological and genetic diversity (Frankham 1995; Lynch 1996).

Common materials for genetic studies in animals are blood or tissue samples, which may affect the integrity of an individual. As a result of this situation and the evasive behavior of many species, non-invasive samples used to obtain DNA include pelage, faeces, urine, saliva, nails and feathers. In addition, the development of techniques such as PCR allows the amplification of specific sequences that have facilitated the genotyping of individuals and the genetic characterization of wild populations (Kohn and York 1999; Pearse and Eckerman 2001; Creel et al. 2003; Wilson and Frantz 2003). In the case of stools, intestinal epithelial cells shed during deposition are used as source of genetic material. However, the low quantity and quality of DNA; and the presence of extraneous DNA from bacteria and preys, as well as PCR inhibitors, can affect the success of amplification (Taberlet and Griffin 1996; Taberlet and Luikart 1999). Accordingly, it is recommended to use fresh stools to avoid the effects of exposure to unfavorable environmental conditions, collect a sufficient sample volume, use primers that amplify short segments, and use appropriate conservation methods to avoid DNA degradation. Chemicals commonly used for preservation include ethanol (EtOH), silica, lysis buffer, and DET (DMSO/Tris/EDTA) buffer. In addition, low temperatures have been suggested (Longmire et al. 1997; Wasser et al. 1997; Frantzen et al. 1998; Taberlet and Luikart 1999; Murphy et al. 2002). There is no consensus on the best method for conservation, since this depends on sample quality, the 
individual specimen, climatic conditions and diet (Murphy et al. 2003, Panasci et al. 2011).

Mitochondrial DNA (mtDNA) sequences are one of the markers most commonly used in non-invasive samples, applied to investigations of genetic diversity, phylogenetic relationships and identification of potential geographical subdivisions between populations (Avise et al. 1987; Bermingham and Moritz 1998; Avise 2000). At the intraspecies level, the score most frequently used is the control region, due to the high mutation rate in its two peripheral domains (Avise 1998; Eizirik and Bonatto 1998; Möller 2001; Montoya-Burgos 2003; Cantanhede and Da Silva 2005; Márquez and Maldonado 2006; Barnett et al. 2006; Tchaicka et al. 2007) In addition, microsatellites -- nuclear markers used in molecular ecology and conservation studies -- are highly variable sequences, with repetitions of two to seven nucleotides that are dispersed throughout the genome in non-coding zones. Microsatellites are widely used to assess intraspecific genetic variations, estimate the effective population size, define management units, determine the origin of populations or individuals, and analyze lineages and reproductive systems, among others (Hedrick 2004; Foerster and Valcu 2006; Crawford et al. 2008). The use of microsatellites in DNA from stools could be limited by genotyping errors, such as null alleles, which occur when only one of the two alleles in a heterozygous individual is amplified, leading to an overestimation of homozygous individuals. Another possibility is the detection of false alleles in homozygous specimens as a result of the amplification of other genome sequences or from contamination, and which might be considered as true alleles; this situation may lead to the misclassification of an individual as a heterozygote. Therefore, care should be taken in selecting the microsatellite markers, choosing preferentially those with repetitions of tetra- or pentanucleotides for a better discrimination of size; also, each amplification should be run at least by triplicate to corroborate the genotype (Taberlet and Luikart 1999; Waits and Paetkau 2005; Pompanon et al. 2005).

Markers linked to sex chromosomes are used for estimating the sex ratio and kinship relationships within a population, as well as for identifying individuals when genotypes are represented in several samples (Smith et al. 2006). Mammals can be sexed by amplifying fragments of the $Y$ chromosome, using the SRY marker, which is co-amplified with a PCR positive control (Dallas et al. 2000). Homologous segments in $X$ chromosomes, such as the "Zinc-finger" marker, can also be amplified (ZFX and ZFY; Park et al. 2011).

These markers have been widely used in genetic studies of carnivorous mammals such as otters (family Mustelidae, subfamily Lutrinae). These mammals are widely distributed worldwide, except for Antarctica and Australia, inhabiting coastal and riparian areas of freshwater and marine ecosystems; their presence depends on prey availability -- basically fish and crustaceans -- and on the quality of the habitat (Kruuk 2006). Otters use droppings and other mucous stools for marking the territory, as a communica- tion strategy, or for coordinating the sexual activity (Parera 1996). Marking usually takes place on dry solid substrates and near water sources (Bardier 1992; Parera 1993; SpinolaParallada and Vaughan-Dickhaut 1995). In the past century, otters were subjected to a high capture pressure driven by fur sales. Despite the prohibition on hunting in many countries and the support of organizations such as the CITES and IUCN, the size of the populations of 12 of the 13 species is still declining, due to the pollution of aquatic environments, the reduction of riparian vegetation in rivers and lagoons, deforestation, and habitat fragmentation (IUCN 2015; Macdonald and Mason 1990; Rosas and Colares 1991; Waldemarin and Alvares 2008). Habitat fragmentation can interrupt gene flow between subpopulations and, consequently, increase the probability of inbreeding and reduce genetic variability as a result of the drift (Lynch and Gabriel 1990).

Since the development of wild mammal conservation programs requires to gain knowledge about the state of populations, genetic studies for otters have been fostered. Several of these studies have focused on the standardization of methodologies to optimize DNA extraction and genotyping. These have shown that fresh mucus and stools are the most appropriate sources for this purpose. Besides, DNA extraction is more efficient using commercial kits, due to the additional purification steps needed with other more affordable methods such as extraction with phenol-chloroform method and the Chelex ${ }^{\circledast} 100$ method (Goossens et al. 2000; Roeder et al. 2004; Hajkova et al. 2006; Lampa et al. 2008; Lerone et al. 2014). When a small amount of DNA is obtained, Lampa et al. (2008) recommend to perform the amplification in two steps, i.e. running a PCR and then repeat it using the product of the first as template DNA; however, this procedure may lead to genotyping errors. To reduce errors in genotype allocation, the PCR should be repeated three times when the locus is heterozygous, and up to seven times if it is homozygous (Taberlet and Griffin 1996), and estimate the rate of occurrence of false and null alleles (Broquet and Petit 2004). Frantz et al. (2003) proposed a method that involves less amplifications, less time and lower costs. When comparing these methods in otter faeces, Hansen et al. (2008) showed that the same genotypes could be obtained. The high costs of genotyping from faeces have fostered the use of other DNA sources such as the pelage, which may also yield more accurate results (Johnson et al. 2013). O'Neill et al. (2013) implemented a real-time PCR to verify the source of stool samples from L. lutra by using specific mtDNA and sexing probes.

Genetic Characterization of Otters from Non-Invasive Samples. The Eurasian otter, Lutra lutra, is the species with the broadest geographical distribution and the best characterized genetically. For this reason, it is a model for the application of conservation genetics methodologies. Most studies coincide in the low mitochondrial genetic diversity of this species, due to the pressures to which it has been subjected, including hunting, water pollution, habitat fragmentation and loss, or to low historical diversity levels (Mucci et al. 1999; 
Cassens and Tiedeman 2000; Ferrando et al. 2004. According to the IUCN (2015), L. lutra is a "near threatened" species. A number of studies have contributed to the development of strategies that have led to the establishment of the species in many areas across Europe (Conroy and Chanin 2002; Mason and Macdonald 2004).

Dallas et al. $(2000 ; 2003)$ used stools as a source of DNA for the first time by comparing the results of the genotyping of 70 samples from carcasses with those from 426 stools. Although only $24 \%$ of samples were suitable for the genotyping analyses, similar results were obtained in terms of estimates of population size, sex ratio and diversity. Later, Hung et al. (2004) estimated the abundance and spatial organization of Lutra lutra in Kinmen island, China, through DNA extraction from 343 stool samples and the amplification of seven microsatellites. A $65 \%$ genotyping was achieved, leading to an estimated population of 38 individuals, 13 of them residents. Population density ranged between 1.5 to 1.8 individuals $/ \mathrm{km}$, with a similar proportion of males and females.

The non-invasive genotyping of samples from different sites allow determining the movements of individuals in a given area. Prigioni et al. (2006) genotyped 214 stool samples with 12 microsatellites, identifying 31 individuals and determining a maximum distance travelled ranging between 0.02 and $34.8 \mathrm{~km} /$ individual.

By genotyping six microsatellites in 427 stool samples and conducting hormone analyses to evaluate the age of individuals in a population of otters in eastern Germany, Kalz et al. (2006) estimated a total of 59 individuals ( 32 males and 27 females), composed of 33 adults and 22 juveniles, as well as a density of one otter for every $4.7 \mathrm{~km}$ of shore.

Genotyping with non-invasive samples has also been used to corroborate the density and population size calculated through ecological methods. Lanszki et al. (2008) found a positive relationship between fresh-stool density and population size through sample genotyping. In a similar study, Arrendal et al. (2007) found that track counts led to an underestimated population size compared with the results of stool genotyping.

Lanszki et al. (2010) found that habitat quality is a key factor that determines population size; when analyzing nine microsatellites in 316 fresh stools in the area adjacent to two fish ponds in Hungary, these authors found a total of 33 individuals, with a higher density in the pond with higher prey availability.

Non-invasive sampling has also been used to confirm the presence of the Eurasian otter in urban areas and estimate the number of individuals. Park et al. (2011) collected 81 excreta in Daegu, South Korea, and verified their origin through the amplification of an otter-specific Cytochrome b segment. The positive amplification of this segment was used for screening out 69 samples, and only 10 of the remaining 12 were efficiently genotyped using 12 microsatellites. The presence of at least seven individuals -- four males and three females - was determined. White et al. (2013) estimated the population size and genetic diversity of L. lutra in Cork (Ireland) through the collection of 199 stool samples, 187 of which were genotyped with nine microsatellites; although only 13 were successfully analyzed, 11 individuals were quantified.

A key contribution of non-invasive sampling has been its application in the evaluation of conservation programs, such as the reintroduction or study of the natural repopulation of the species. Ferrando et al. (2007) evaluated the success of the reintroduction of L. lutra in northeastern Spain, through the genotyping of invasive samples from introduced individuals and stool samples collected approximately 10 years after the reintroduction process started. These researchers found that the founding population had been replaced by their offspring and that the species had spread to its previous distribution range. Similarly, in the north of the Netherlands, Koelewijn et al. (2010) monitored a reintroduced population of 30 individuals over six years by genotyping 1,265 stool samples using between seven and 15 microsatellites. These authors identified 15 individuals of the founder population and 54 descendants, and found that females and males started mating at two and four years of age, respectively. To evaluate the recovery of Lutra lutra in Spain, Vergara et al. (2014) genotyped 128 stool samples with 11 microsatellites and estimated 20 individuals, with a density between 0.06 and 0.12 individuals/

Table 1. Genotyping success in genetic characterization studies of otters with microsatellite markers that used stool samples as source of DNA. Number of samples (n). Number of markers (NM), Genotyping success Gs

\begin{tabular}{|c|c|c|c|c|c|}
\hline Species & $\mathbf{n}$ & NM & $\begin{array}{l}\text { Conservation } \\
\text { method }\end{array}$ & Gs & Reference \\
\hline \multirow[t]{14}{*}{ L. lutra } & 68 & $1(\mathrm{SRY})$ & $\mathrm{EtOH}(95 \%)$ and $20^{\circ} \mathrm{C}$ & $60 \%$ & Dallas et al. (2000) \\
\hline & 426 & 9 & * & $20 \%$ & Dallas et al. (2003) \\
\hline & 343 & 7 & $\mathrm{EtOH}(100 \%)$ and $80^{\circ} \mathrm{C}$ & $65 \%$ & Hung et al. (2004) \\
\hline & 214 & 12 & * & $48 \%$ & Prigioni et al. (2006) \\
\hline & 427 & 6 & * & $24 \%$ & Kalz et al. (2006) \\
\hline & 150 & 8 & $-22^{\circ} \mathrm{C}$ & $38 \%$ & Arrendal et al. (2007) \\
\hline & 92 & 9 & $\operatorname{EtOH}(96 \%)$ and $20^{\circ} \mathrm{C}$ & $14 \%$ & Lanszki et al. (2007) \\
\hline & 104 & 10 & $\mathrm{EtOH}(96 \%)$ and $20^{\circ} \mathrm{C}$ & $25 \%$ & Ferrando et al. (2008) \\
\hline & 316 & 9 & $\mathrm{EtOH}(96 \%)$ and $20^{\circ} \mathrm{C}$ & $15 \%$ & Lanszki et al. (2009) \\
\hline & 448 & 10 & $\operatorname{EtOH}(96 \%)$ and $20^{\circ} \mathrm{C}$ & $60 \%$ & San Onofre Loft et al. (2006) \\
\hline & 12 & 12 & $\mathrm{EtOH}(100 \%)$ and $70^{\circ} \mathrm{C}$ & $83 \%$ & Park et al. (2011) \\
\hline & 1,265 & $7-15$ & $\mathrm{EtOH}(99 \%)$ and $20^{\circ} \mathrm{C}$ & $46 \%$ & Koelewijn et al. (2012) \\
\hline & 187 & 13 & $-20^{\circ} \mathrm{C}$ & $7 \%$ & White et al. (2013) \\
\hline & 128 & 11 & $\mathrm{EtOH}(96 \%)$ and $20^{\circ} \mathrm{C}$ & $43 \%$ & Vergara et al. (2014) \\
\hline \multirow[t]{4}{*}{ L. canadensis } & 48 & 4 & EtOH $(100 \%)$ and $4^{\circ} \mathrm{C}$ & $56 \%$ & Hansen et al. 2008 \\
\hline & 839 & & $\mathrm{EtOH}(100 \%)$ and $4^{\circ} \mathrm{C}$ & $12 \%$ & Guertin et al. (2012) \\
\hline & 1,421 & 10 & $-20^{\circ} \mathrm{C}$ & $24 \%$ & Mowry et al. (2011) \\
\hline & 490 & 6 & $-20^{\circ} \mathrm{C}$ & $25 \%$ & Brzeski et al. (2013) \\
\hline \multirow[t]{2}{*}{ P. brasiliensis } & 20 & 34 & EtOH & $60 \%$ & Pickles et al. (2009) \\
\hline & 170 & 13 & $*$ & $41 \%$ & Pickles et al.(2011b) \\
\hline \multirow[t]{4}{*}{ L. longicaudis } & 43 & 5 & Silica and $-18^{\circ} \mathrm{C}$ & $37 \%$ & Weber et al. (2009) \\
\hline & 623 & 8 & Silica & $24 \%$ & Ortega et al. (2012) \\
\hline & 253 & 8 & $\mathrm{EtOH}(96 \%)$ and $-20^{\circ} \mathrm{C}$ & * & Trinca et al. (2013) \\
\hline & 36 & 8 & $\mathrm{EtOH}(96 \%)$ and $-20^{\circ} \mathrm{C}$ & $55 \%$ & Trigila et al. (2015) \\
\hline
\end{tabular}


$\mathrm{km}$. Based on previous records, these authors recognized a slight recovery of the otter population in the area.

The North American river otter Lontra canadensis dwells in lakes and rivers of North America and is categorized by the IUCN (2015) as a species of "least concern". Studies on $L$. canadensis have proposed methods to optimize the amplification and reduce the amount of PCR required to obtain a reliable genotype. In addition, specific primers have been developed for the amplification of microsatellites (Beheler et al. 2005; Hansen et al. 2008). Non-invasive sampling was used for the first time in this species to relate the genetic results to exposure to pollutants. Guertin et al. (2010) quantified polyhalogenated aromatic hydrocarbons in faeces of L. canadensis in Vancouver, Canada, which were genotyped based on eight microsatellites. Only $12 \%$ of 893 samples yielded a consensus genotype, represented by 49 individuals. From the data in this research, Guertin et al. (2012) found that although the survival and reproductive success of the otter were high in polluted sites, density was lower than in less polluted areas, likely due to the emigration of otters to habitats in a better conservation state.

The genotyping of faeces in L. canadensis has also been used for estimating the size of reintroduced populations. In a region of Missouri (U.S.A), Mowry et al. (2011) genotyped 1.421 excreta with 10 microsatellites; markers SRY and ZFX/ZFY were used for determining in sexing. Twenty four per cent of the samples were genotyped, resulting in 63 individuals identified and an approximate density of 0.239 otters $/ \mathrm{km}$, with a higher proportion of males versus females. Mowry et al. (2015) found a low (0.283) genetic diversity of the mtDNA control region in the otter population in Missouri compared with Louisiana (0.607), the place of origin of the individuals reintroduced in Missouri.

Non-invasive sampling is frequently used for creating population demography baselines. Brzeski et al. (2013) estimated the abundance of the sea otter in the Humboldt Bay (U.S.A.) from the amplification of six microsatellites in $\mathbf{4 9 0}$ stool samples. Twenty five per cent of these samples could be genotyped, corresponding to 40 individuals; the density obtained was 0.93 otters $/ \mathrm{km}$. Through direct observation, it was found that the size of the group varied between one and seven individuals, while genotyping showed that it was between two and 12 individuals.

The giant Brazilian otter, Pteronura brasiliensis, is a species of larger size; although it originally spanned across central areas of northern South America (Eisenberg 1989), its current range has been reduced (Oliveira et al. 2012). The species is classified as "Endangered" by the IUCN (2015). In this species, mitochondrial markers in non-invasive samples were used for the first time for investigating the genetic diversity, geographical structure and evolutionary history of otters. Garcia et al. (2007) conducted the genetic characterization of $P$. brasiliensis populations in northern and southern Brazil through the amplification and sequencing of three mtDNA regions from the feces of 13 wild otters, as well as from tissue and blood of 17 otters in captivity or dead. These authors found a high haplotype diversity and a low nucleotide diversity $(H=0.867$ and $\pi=0.006)$. The populations shared only one haplotype, suggesting a low gene flow; however, the genetic structuring analysis was not significant.

To investigate the evolutionary history of $P$. brasiliensis, Pickles et al. (2011a). Amplified the control region and cytochrome b in 70 samples collected in eight countries across South America (38 feces and 32 blood and tissue samples). Finding a high haplotype diversity $(H=0.93)$ and a marked phylogeographic structure across the distribution range of the species.

Caballero et al. (2015) investigated the population structure and genetic diversity of $P$. brasiliensis in the Colombian Orinoquía from the sequencing of the mitochondrial DNA control region of 54 stool and five tissue samples. These authors obtained 39 sequences of the region of interest that led to 15 haplotypes, the majority corresponding to a phylogenetic group that had not been described previously for this species.

With regard to the use of microsatellite markers, Pickles et al. (2009) analyzed the effectiveness of amplification and the degree of polymorphism of 34 markers developed for Lutra lutra (19) and Lontra canadensis (15) in 20 stool samples of $P$. brasiliensis collected in the Amazonian basin of Bolivia. These authors were able to amplify $60 \%$ of samples, and 32 of the 34 loci were effective. From these results, Pickles et al. (2011b) selected 13 microsatellites to establish the genetic diversity and structuring patterns of four populations of the giant otter in South America. Forty five per cent of 170 stool samples were successfully genotyped, leading to an estimated population size of 59 individuals.

The Neotropical otter, Lontra longicaudis, shows the wider distribution range in America, although recent studies show that this species is "near threatened" across most of its range (Rheingantz and Trinca 2015). For the first genetic characterization of the mtDNA control region of the Neotropical otter, Trinca et al. (2007) extracted DNA from four stool samples and 20 tissue and blood samples collected in southern of Brazil. The sequencing of this segment revealed a high haplotype diversity (0.819) and a low nucleotide diversity (0.0049), seemingly associated with recent diversification process. Subsequently, Trinca et al. (2012) amplified three mtDNA segments from four stool samples and 48 blood and tissue samples collected in a vast area of South America. The results showed a high genetic diversity $(H=0.9694, \pi$ $=0.00814$ ) and the presence of four different evolutionary lineages, partially consistent with the three subspecies proposed for the species.

In three regions of Mexico, Guerrero et al. (2015) collected stools, hair and muscle tissue of the Neotropical otter, aimed at estimating the genetic diversity and demographic history using mitochondrial markers. These authors identified 44 individuals and 11 haplotypes, with a total genetic diversity that was lower than the one reported in previous studies for the species $(H=0.7620, \pi=0.0023)$, and found evidence of 
genetic structuring. Phylogenetic analyses with the haplotypes reported in Central and South America made possible to identify a monophyletic lineage in North and Central America that may represent an Evolutionarily Significant Unit (ESU), consistent with the assignment by Trinca et al. (2012).

In the first study of $L$. longicaudis using nuclear markers, Weber et al. (2009) collected 43 stool samples in the state of Rio Grande do Sul and tested the amplification of five microsatellites developed for Lutra lutra. The genotyping efficiency reached $37 \%$ and 24 genotypes were detected. Although the actual number of alleles was high, these authors found a heterozygous deficiency in all loci and a low genetic differentiation between the sites evaluated.

In the Lacantún fluvial system (Mexico), Ortega et al. (2012) assessed the dispersal and genetic structure of the Neotropical otter through the amplification of eight microsatellite and the ZXY marker in 623 stool samples. The genotyping success was $24.4 \%$, finding 34 unique genotypes, high dispersal levels, low genetic differentiation levels and a similar sex ratio.

Trinca et al. (2013) evaluated the population size, spacetime organization and kinship relationships of the Neotropical otter in southern Brazil through the genotyping of eigth microsatellites in 253 stool samples. From a $41.1 \%$ amplification success, these authors estimated the presence of 28 individuals and a density of approximately one otter $/ \mathrm{km}$. In addition, they found a high genetic diversity, accounted for by the high proportion of alleles per loci. The proportion of females and males was similar. While males moved across large areas, females showed a more phylopatric behavior. The reconstruction of genealogies showed that the spatial organization of otters is influenced by kinship.

Trigila et al. (2016) used eight microsatellites for genotyping 36 stool specimens of L. longicaudis in the Paraná river delta (Argentina). These authors genotyped $54.8 \%$ of samples and identified 29 individuals. The low heterozygosity found was consistent with the high degree of kinship; in addition, they found a positive correlation between habitat quality and genetic diversity.

The southern river otter, Lontra provocax, is the species with the most restricted geographical distribution, thriving in the Patagonia, and is classified as "Endangered" by the IUCN (2015). The few genetic studies for this species are based on mitochondrial markers. To compare the genetic diversity of $L$. provocax in the north and south of the Argentine Patagonia, Centrón et al. (2008) amplified the control region and cytochrome $b$ from 150 stool samples. Only 13 sequences were obtained in the control region, represented by a single haplotype, and 34 sequences of cytochrome b, with four haplotypes. Vianna et al. (2011) analyzed the phylogeographic patterns and the population structure of $L$. provocax in marine and limnetic environments through the amplification and sequencing of three mitochondrial segments in 75 samples ( 57 stool and 18 tissue samples). These researchers found 17 haplotypes and a strong genetic dif- ferentiation between otters of the two habitats. The phylogeographic evidence suggests that the adaptation to marine habitats resulted from the presence of a shelter during the Last Glacial Maximum.

The southern sea otter, Lontra felina, is the smallest otter, is distributed along the coasts of Peru and Chile, and is classified as "Endangered" by the IUCN (2015). In this species, only mitochondrial markers have been applied in genetic diversity studies. Valqui et al. (2010) characterized the mtDNA control region in 87 stool samples of $L$. felina collected in the Peruvian coast, 37 of which being successfully amplified and sequenced. These authors found a high haplotype diversity, represented by 11 haplotypes, and found no evidence of genetic structuring in the area studied.

The high genetic diversity of this species in the Peruvian coast was confirmed by Vianna et al. (2010) in an investigation on its evolutionary history, by sequencing three mtDNA segments in 357 stool, 16 blood and 46 carcasse samples collected along the coasts of Peru and Chile. The success of amplification and sequencing was $35 \%$, with a higher genetic diversity of otters in the coasts of Peru vs. Chile. A strong geographic structuring was evidenced, and the phylogenetic analysis showed that $L$. felina diverged from L. provocax.

The available information evidences the advantages of using genetic diversity markers in non-invasive samples, since it is possible to obtain high-quality amplifications for the genotyping of individuals. In the case of microsatellites, genotyping success varied between $7 \%$ and $65 \%$, likely due to differences in sample quality and preservation method. In addition, the number of markers used varied; therefore, it is possible that works involving a lower number of markers report a higher genotyping success (Table 1). It is worth mentioning that the majority of studies performed multiple amplifications and quantified genotyping errors according to the proposal of Taberlet and Luikart 1999; other studies are not clear in this respect, which may also have biased the results.

As there is no consensus on the genotyping methodology for stool samples, it is recommended to standardize the experimental conditions. Initially, the microsatellites to use should be evaluated, selecting those that are polymorphic in the population; the number of tandem repetitions should include at least three nucleotides in order to accurately estimate the size of alleles (Taberlet and Griffin 1996; Taberlet and Luikart 1999). When markers are applied for the first time, their functioning in the species of interest should be checked; to date, microsatellite markers have been developed for Lutra lutra and Lontra canadensis, and their application to other related species has been effective. Finally, to obtain a reliable genotype it is necessary to repeat the amplifications to achieve a genotype consensus and estimate the rate of occurrence of null and false alleles. The available information indicates that non-invasive samples were initially used to estimate the number of individu- 
als and population structure. Then, these were applied to evaluate the success of reintroduction and management programs. In addition, the use of genotyping coupled with measurement of toxic substances in stool made possible to better explain the demographics and genetic diversity of populations of Lontra canadensis. It is key to conduct these studies in other otter species exposed to pollution, in order to establish their response to these conditions.

Mitochondrial DNA, as a marker of diversity in noninvasive samples, has been used in a few studies as a first approach to the genetic diversity and evolutionary history of species. This marker shows a more efficient amplification vs. microsatellite markers, since a single cell has numerous mitochondria and hence many mtDNA copies. However, with this marker the number of individuals represented in the samples analyzed is uncertain; therefore, it should be applied concurrently with microsatellite markers, so that separate individuals can be differentiated. When used together, both markers can provide a broader overview on the genetic diversity, demography, ecology, evolutionary history and behavior of otter species; in turn, this information may lead to an earlier identification of the impact of environmental changes on otter populations and the design of appropriate conservation strategies.

\section{Acknowledgments}

The authors would like to thank the University of Antioquia and Empresas Públicas de Medellin for the support provided during the Master's Degree in Environmental Sciences. We are also grateful to two anonymous reviewers whose comments helped improve the quality of the manuscript. María Elena Sánchez-Salazar translated the manuscript into English.

\section{Literature cited}

ARrendaL, J., C. VILÀ, AND M. BJörKLund. 2007. Reliability of noninvasive genetic census of otters compared to field censuses. Conservation Genetics 8:1097-1107.

AvISE,J., J. ARNOLD, AND R. BALL. 1987. Intraspecific phylogeography: the mitochondrial DNA bridge between population genetics and systematics. Annual review of ecology and systematics XX:489-522.

AvISE, J. 1998. Conservation genetics in the marine realm. Journal of Heredity 89:377-382.

AvISE, J. 2000. Phylogeography: the history and formation of species. Harvard University Press. Cambridge, U. S. A.

BARDIER, G. 1992. Uso de recursos y características del hábitat del Lobito de río. Lutra longicaudis en el arroyo Sauce, SE de Uruguay. Boletín de la Sociedad Zoológica del Uruguay 7:59-60.

Barnett, R., N. Yamaguchi, I. Barnes, and A. Cooper. 2006. Lost populations and preserving genetic diversity in the lion Panthera leo: implications for its ex situ conservation. Conservation Genetics 7:507-514.

Beheler, A. S., J. A. Fike, G. Dharmarajan, O. E. Rhodes, and T. L. Serfass. 2005. Ten new polymorphic microsatellite loci for North American river otters (Lontra canadensis) and their utility in related mustelids. Molecular Ecology Notes 5:602-604.
Bermingham, E., and C. Moritz. 1998. Comparative phylogeography: concepts and applications. Molecular Ecology 7:367-369.

Broquet, T., AND E. Petit. 2004. Quantifying genotyping errors in noninvasive population genetics. Molecular Ecology 13:3601-3068.

BRZESKI, K. E., M. S. GUNTHER, AND J. M. BLACK. 2013. Evaluating river otter demography using noninvasive genetic methods. The Journal of Wildlife Management 77:1523-1531.

Caballero, S., C. A. Correa-Cárdenas, and F. Trujlllo. 2015. Population structure and genetic diversity of the endangered South American giant otter (Pteronura brasiliensis) from the Orinoco Basin in Colombia: management implications and application to current conservation programs. Journal of Heredity 106:469-477.

Cantanhede, A., And V. Da Silva. 2005. Phylogeography and population genetics of the endangered Amazonian manatee, Trichechus inunguis Natterer, 1883 (Mammalia, Sirenia). Molecular Ecology 14:401-413.

CASSENS, I., AND R. TIEDEMAN. 2000. Mitochondrial DNA variation in the European otter (Lutra lutra) and the use of spatial autocorrelation analysis in conservation. Journal of Heredity 9:31-35.

Centrón, D., B. Ramirez, L. Fasola, D. W. Macdonald, C. Chehébar, A. SCHIAVINI, AND M. H. CASSINI. 2008. Diversity of mtDNA in Southern River Otter (Lontra provocax) from Argentinean Patagonia. The Journal of heredity 99:198-201.

CONROY, J., AND P. CHANIN. 2002. The status of the Eurasian otter (Lutra lutra). IUCN Otter Specialist Group Bulletin A Review 1:7-28.

Crawford, J., Z. LiU, AND T. Nelson. 2008. Microsatellite analysis of mating and kinship in beavers (Castor canadensis). Journal of Mammalogy 89:575-581.

CReEL, S., G. Spong, AND J. SAnds. 2003. Population size estimation in Yellowstone wolves with error-prone noninvasive microsatellite genotypes. Molecular ecology 12:XX.

Dallas, J. F., D. N. Carss, F. Marshall, K. P. Koepfl, H. KruUK, P. J. Bacon, AND S. B. PIERTNEY. 2000. Sex identification of the Eurasian otter Lutra lutra by PCR typing of spraints. Conservation Genetics 1:181-183.

Dallas, J. F., K. E. Coxon, T. Sykes, P. R.Chanin, F. Marshall, D. N. CARSS, AND P. A. RACEY, P. 2003. Similar estimates of population genetic composition and sex ratio derived from carcasses and faeces of Eurasian otter Lutra lutra. Molecular Ecology 12:275-82.

EISENBERG, J. 1989. Mammals of the Neotropics: The Northern Neotropics (Vol. 1). University of Chicago Press. Chicago, U. S. A. EizIRIK, E., AND S. Bonatto. 1998. Phylogeographic patterns and evolution of the mitochondrial DNA control region in two Neotropical cats (Mammalia, Felidae). Journal of Molecular Evolution 47:613-624.

Ferrando, A., M. PonsA, J. Marmi, and X. Domingo-Roura. 2004. Eurasian otters, Lutra lutra, have a dominant mtDNA haplotype from the Iberian Peninsula to Scandinavia. The Journal of heredity 95:430- 435 .

Ferrando, A., R. Lecis, X. Domingo-Roura, and M. Ponsà. 2007. Genetic diversity and individual identification of reintroduced otters (Lutra lutra) in north-eastern Spain by DNA genotyping of spraints. Conservation Genetics 9:129-139.

Foerster, K., AND M. Valcu. 2006. A spatial genetic structure and effects of relatedness on mate choice in a wild bird 
population. Molecular Ecology 15:4555-4567.

FranKham, R. 1995. Conservation genetics. Annual Review of Genetics 29:305-327.

Frankham, R., D. A Briscoe, and J. D. Ballou. 2002. Introduction to Conservation Genetics, Cambridge University Press. Cambridge, Inglaterra.

Frantz, A., L. Pope, and P. Carpenter. 2003. Reliable microsatellite genotyping of the Eurasian badger (Meles meles) using faecal DNA. Molecular Ecology 12:1649-1661.

Frantzen, M. A. J., J. B. Silk, J. W. H. Ferguson, R. K. Wayne, and M. H. KoHN. 1998. Empirical evaluation of preservation methods for faecal DNA. Molecular Ecology 7:1423-1428.

Garcia, D. M., M. Marmontel, F. W. Rosas, and F. R. Santos. 2007. Conservation genetics of the giant otter (Pteronura brasiliensis (Zimmerman, 1780)) (Carnivora, Mustelidae). Brazilian Journal of Biolog 67:819-27.

Goossens, B., L. ChiKhi, S. S. Utami, J. De Ruiter, And M. W. Bruford. 2000. A multi-samples, multi-extracts approach for microsatellite analysis of faecal samples in an arboreal ape. Conservation genetics 1:157-162.

Guerrero, J., J. P. Gallo-Reynoso, and R. Biek. 2015. Mitochondrial DNA diversity, genetic structure, and demographic history of the Neotropical otter (Lontra longicaudis) in Mexico. Journal of Mammalogy 96:1162-1173.

Guertin, D. A., A. S. Harestad, M. Ben-David, K. G. Drouillard, and J. E. ElLIOTt. 2010. Fecal genotyping and contaminant analyses reveal variation in individual river otter exposure to localized persistent contaminants. Environmental Toxicology and Chemistry 29:275-284.

Guertin, D. A., M. Ben-David, A. S. Harestad, and J. E. Elliott. 2012. Fecal genotyping reveals demographic variation in river otters inhabiting a contaminated environment. The Journal of Wildlife Management 76:1540-1550.

Hájková, P., B. Zemanová, J. Bryja, B. Hájek, K. Roche, E. Tkadlec, and J. ZIMA. 2006. Factors affecting success of PCR amplification of microsatellite loci from otter faeces. Molecular Ecology Notes 6:559-562.

Hansen, H., M. Ben-David, and D.B. Mcdonald. 2008. Effects of genotyping protocols on success and errors in identifying individual river otters (Lontra canadensis) from their faeces. Molecular ecology resources 8:282-9.

HEDRICK, P. W. 2001. Conservation genetics: where are we now? Trends in Ecology and Evolution 16:629-636.

HedRICK, P. W. 2004. Recent developments in conservation genetics. Forest Ecology and Management 197:3-19.

Hung, C. M., S. H. LI, And L. L. LeE. 2004. Faecal DNA typing to determine the abundance and spatial organisation of otters (Lutra lutra) along two stream systems in Kinmen. Animal Conservation 7:301-311.

IUCN. 2015. The IUCN Red List of Threatened Species 2015. www.iucnredlist.org. Downloaded on 10 June 2016.

Johnson, C .J., D. P. Hodder, And S. Crowley. 2013. Assessing noninvasive hair and fecal sampling for monitoring the distribution and abundance of river otter. Ecological Research 28:881-892.

Kalz, B., K. JeWGENOW, AND J. FICKEL. 2006. Structure of an otter (Lutra lutra) population in Germany - results of DNA and hormone analyses from faecal samples. Mammalian Biology 71:321-335.

Koelewijn, H. P., M. Pérez-Haro, H. A. H. Jansman, M. C. Boerwinkel,
J. Bovenschen, D. R. Lammertsma, and A.T. Kuiters. 2010. The reintroduction of the Eurasian otter (Lutra lutra) into the Netherlands: hidden life revealed by noninvasive genetic monitoring. Conservation Genetics 11:601-614.

KoHN, M., AND E. York. 1999. Estimating population size by genotyping faeces. Proceedings of the Royal Society of London 266:657-663.

KRUUK, H. 2006. Otters: ecology, behaviour and conservation. Oxford University Press. Oxford, United Kindom.

Lampa, S., B. Gruber, K. Henle, and M. Hoehn. 2008. An optimisation approach to increase DNA amplification success of otter faeces. Conservation Genetics 9:201-210.

Lanszki, J., A. HidAs, K. Szentes, T. Révay, I. Lehoczky, Z. Jeney, and S. Weiss. 2010. Genetic structure of otter (Lutra lutra) populations from two fishpond systems in Hungary. Mammalian Biology 75:447-450.

Lanszki, J., A. Hidas, K. Szentes, T. Révay, I. Lehoczky, and S. Weiss. 2008. Relative spraint density and genetic structure of otter (Lutra lutra) along the Drava River in Hungary. Mammalian Biology 73:40-47.

Lerone, L., C. Mengoni, G. M. Carpaneto, E. Randi, and A. Loy. 2014. Procedures to genotype problematic non-invasive otter (Lutra lutra) samples. Acta Theriologica 59:511-520.

LONGmiRE, J. L., M. MALtBiE, AND R. J. BAKer. 1997. Use of "Lysis Buffer" in DNA isolation and its implication for museum collections. Occasional papers, The Museum of Texas Tech University 163:1-3.

LYNCH, M. 1996. A quantitative-genetic perspective on conservation issues. Pp. 471-501 in Conservation Genetics: Case Histories from Nature (Avise, J. C., and J. L. Hamrick, eds.). Chapman y Hall. New York, U. S. A.

LYNCH, M., AND W. GABRIEL. 1990. Mutation load and the survival of small populations. Evolution 44:1725-1737.

Macdonald, S., AND C. Mason. 1990. Action plan for European otters. Pp. 29-40 in Otters: An Action Plan for their Conservation (Foster-Turley, P., S. Macdonald, and C. F. Mason eds). IUCN otter specialist group. Gland, Suiza.

Márquez, A., and J. Maldonado. 2006. Phylogeography and Pleistocene demographic history of the endangered marsh deer (Blastocerus dichotomus) from the Río de la Plata Basin. Conservation Genetics 7:563-575.

MASON, C., AND S. MACDONALD. 2004. Growth in otter (Lutra lutra) populations in the UK as shown by long-term monitoring. A Journal of the Human Environment 33:148-152.

MöLleR, L. 2001. Alliance membership and kinship in wild male bottlenose dolphins (Tursiops aduncus) of southeastern Australia. Proceedings of the Royal Society of London. Series B: Biological Sciences 268:1941-1947.

Montoya-Burgos, J. 2003. Historical biogeography of the catfish genus Hypostomus (Siluriformes: Loricariidae), with implications on the diversification of Neotropical ichthyofauna. Molecular Ecology 12:1855-1867.

MoRITZ, C. 2002. Strategies to protect biological diversity and the evolutionary processes that sustain it. Systematic Biology 51:238-254.

Mowry, R. A., M. E. Gompper, J. Beringer, And L. S. Eggert. 2011. River otter population size estimation using noninvasive latrine surveys. The Journal of Wildlife Management 75:1625-1636. Mowry, R. A., T. M. Schneider, E. K. LATCH, M. E. Gompper, J. Beringer, AND L. S. EGGERT. 2015. Genetics and the successful reintroduction of the Missouri river otter. Animal Conservation 18:196-206. 
Mucci, N., C. Pertoldi, A. B Madsen, V. LoeschCKe, and E. Randi. 1999. Extremely Low Mitochondrial DNA Control-Region Sequence Variation in the Otter Lutra lutra Population of Denmark. Hereditas 130:331-336.

Murphy, M. A., L. P. Waits, K. C. Kendall, S. K. Wasser, J. A. Higbee Y R. Bogden. 2002. An evaluation of long-term preservation methods for brown bear (Ursus arctos) faecal DNA samples. Conservation genetics 3:435-440.

Murphy, M. A., L. P. Waits, And K. C. Kendall. 2003. The influence of diet on faecal DNA amplification and sex identification in brown bears (Ursus arctos). Molecular Ecology 12:2261-2265. Oliveira De, L. R., R. Loizaga De Castro, S. Cárdenas-Alayza, and S. L. Bonatto. 2012. Conservation genetics of South American aquatic mammals: an overview of gene diversity, population structure, phylogeography, non-invasive methods and forensics. Mammal Review 42:275-303.

O'Neill, D., P. D. Turner, D. B. O'Meara, E. A. Chadwick, L. Coffey, and C. O’ReIlly. 2013. Development of novel real-time TaqMan ${ }^{\circledR}$ PCR assays for the species and sex identification of otter (Lutra lutra) and their application to noninvasive genetic monitoring. Molecular ecology resources 13:877-883.

Ortega J., D. Navarrete, and J. E. Maldonado. 2012. Non-invasive sampling of endangered neotropical river otters reveals high levels of dispersion in the Lacantun River System of Chiapas, Mexico. Animal Biodiversity and Conservation 35:59-69.

Parera, A. 1996. Las "nutrias verdaderas" de la Argentina. Fundación Vida Silvestre Argentina. Buenos Aires, Argentina. PARERA, A. 1993. The neotropical river otter Lutra longicaudis in Iberá lagoon, Argentina. IUCN Otter Spec Group Bull 8:13-16. PARK, H. C., T. Y. HAN, D. C. KIM, M. S. MIN, S. Y. HAN, K. S. KIM, AND H. LEE. 2011. Individual identification and sex determination of Eurasian otters (Lutra lutra) in Daegu city based on genetic analysis of otter spraint. Genes and Genomics 33:653-657.

Panasci, M., W. B. Ballard, S. Breck, D. Rodriguez, L. D. Densmore, D. B. WESTER, AND R. J. BAKER. 2011. Evaluation of fecal DNA preservation techniques and effects of sample age and diet on genotyping success. The Journal of wildlife management 75:1616-1624.

Pearse, D., and C. Eckerman. 2001. A genetic analogue of "mark-recapture"methods for estimating population size: an approach based on molecular parentage assessments. Molecular Ecology 10:2711-2718.

PiCkles, R. S., J. J. Groombridge, V. D. Z. Rojas, and W. C. Jordan. 2009. Cross-species characterisation of polymorphic microsatellite loci in the giant otter (Pteronura brasiliensis). Molecular ecology resources 9:415-417.

Pickles, R. S., J. J. Groombridge, V. Z. Rojas, P. Van Damme, D. Gottell, S. Kundu, AND W. C. JoRdan. 2011a. Evolutionary history and identification of conservation units in the giant otter, Pteronura brasiliensis. Molecular phylogenetics and evolution 61:616-627.

Pickles, R. S., J. J. Groombridge, V. Z. Rojas, P. Van Damme, D. Gottelli, C. V. Ariani, And W. C. Jordan. 2011b. Genetic diversity and population structure in the endangered giant otter, Pteronura brasiliensis. Conservation Genetics 13:235-245.

Pompanon, F., A. Bonin, E. Bellemain, and P. Taberlet. 2005. Genotyping errors: causes,consequences and solutions. Natural Revision in Genetics 6:847-849.

Prigioni, C. L., L. U. Remontı, And A. L. Balestrieri. 2006. Otter Lutra lutra movements assessed by genotyped spraints in southern Italy. Hystrix, the Italian Journal of Mammalogy 17:91-96.
Rheingantz, M .L., And C. S. Trinca. 2015. Lontra longicaudis. The IUCN Red List of Threatened Species 2015:e. T12304A21937379. http://dx.doi.org/10.2305/IUCN. UK.2015- 2.RLTS.T12304A21937379.

Roeder, A. D., F. I. Archer, H. N. Poinar, and P. A. Morin. 2004. A novel method for collection and preservation of faeces for genetic studies. Molecular Ecology Notes 4:761-764.

Rosas, F., and E. Colares. 1991. Mamíferos aquáticos da Amazônia brasileira. Pp 405-411 in Bases científicas para o estabelecimento de estratégias de preservação e desenvolvimento da Amazônia: fatos e perspectivas (Val, A. L., R. Figliuolo, and E. Feldsberg, eds.). Manaus. Brasil.

Smith, D. A., K. Ralls, A. Hurt, B. Adams, M. Parker, and J. E. MaldonAdo. 2006. Assessing reliability of microsatellite genotypes from kit fox faecal samples using genetic and GIS analyses. Molecular Ecology 15:387-406.

Sinola-Parallada, R., And C. VAughan-Dickhaut. 1995. Abundancia relativa y actividad de marcaje de la nutria neotropical (Lutra longicaudis) en Costa Rica. Vida Silvestre Neotropical 4:38-45. TABERLET, P., AND S. GRIFFIN. 1996. Reliable genotyping of samples with very low DNA quantities using PCR. Nucleic Acids 24:3189-3194.

TABERLEt, P., AND G. LUIKART. 1999. Non-invasive genetic sampling and individual identification. Biological Journal of the Linnean Society 68:41-55.

TChaicka, L., E. Eizirik, T. G. De Oliveira, J. F. CÂndido, and T. R. Freitas. 2007. Phylogeography and population history of the crabeating fox (Cerdocyon thous). Molecular Ecology 16:819-38.

TriGiLA, A. P., J. J. Gómez, M. H. CASSINI, AND J. I. Túnez. 2016. Genetic diversity in the Neotropical river otter, Lontra longicaudis (Mammalia, Mustelidae), in the Lower Delta of Parana River, Argentina and its relation with habitat suitability. Hydrobiologia 768:287-298.

Trinca, C. S., B. De Thoisy, F. C. Rosas, H. F. Waldemarin, K. P. Koepfli, J. A. Vianna, and E. EiziRIK. 2012. Phylogeography and demographic history of the neotropical otter (Lontra longicaudis). The Journal of heredity 103:479-92.

TrincA, C. S., C. F. JAEGER, AND E. EIZIRIK. 2013. Molecular ecology of the Neotropical otter (Lontra longicaudis): non-invasive sampling yields insights into local population dynamics. Biological Journal of the Linnean Society 109:932-948.

Trinca, C. S., H. F. Waldemarin, and E. Eizirik. 2007. Genetic diversity of the Neotropical otter (Lontra longicaudis Olfers, 1818) in Southern and Southeastern Brazil. Brazilian Journal of Biology 67:813-8.

Valqui, J., G. B. Hartl, and F. E. Zachos. 2010. Non-invasive genetic analysis reveals high levels of mtDNA variability in the endangered South-American marine otter (Lontra felina). Conservation Genetics 11:2067-2072.

Vergara, M., A. Ruiz-González, J. L. De Luzuriaga, and B. J. GómezMOLINER. 2014. Individual identification and distribution assessment of otters (Lutra lutra) through non-invasive genetic sampling: Recovery of an endangered species in the Basque Country (Northern Spain). Mammalian Biology 79:259-267.

Vianna, J. A., P. Ayerdi, G. Medina-Vogel, J. C. Mangel, H. Zeballos, M. Apaza, And S. Faugeron. 2010. Phylogeography of the Marine Otter (Lontra felina): historical and contemporary factors determining its distribution. The Journal of heredity 101:676-689. 
Vianna, J. A., G. Medina-Vogel, C. Chehébar, W. Sielfeld, C. Olavarría, And S. Faugeron. 2011. Phylogeography of the Patagonian otter Lontra provocax: adaptive divergence to marine habitat or signature of southern glacial refugia? BMC evolutionary biology 11:53

Waits, L., And D. PaetKau. 2005. Noninvasive genetic sampling tools for wildlife biologists: a review of applications and recommendations for accurate data collection. Journal of Wildlife Management 69:1419-1433.

Waldemarin, H., ANd R. Alvares. 2008. Lontra longicaudis. IUCN 2010. Lista Roja de Especies Amenazadas IUCN. Versión 2010.1.

Wasser, S. K., C. S. Houston, G. M. Koehler, G. G. Cadd, and S. R. Fain. 1997. Techniques for application of faecal DNA methods to field studies of ursids. Molecular Ecology 6:1091-1097.

Weber, L. I., C. G. Hildebrand, A. Ferreira, G. Pedarassi, J. A. Levy, And E. P. ColARES. 2009. Microsatellite genotyping from faeces of Lontra longicaudis from southern Brazil. REVISTA, 99:5-11.

White, S., D. D. B. O'meara, C. Shores, C. O. R. A. P Harrington, G. Weyman, and D. Sleeman. 2013. A non-invasive genetic survey of otters (Lutra lutra) in an urban environment : A pilot study with citizen scientists. IUCN Otter Specialist Group Bulletin 30:103-111.

Wilson, G., AND A. Frantz. 2003. Estimation of badger abundance using faecal DNA typing. Journal of Applied Ecology 40:658-666.

Associated editor: Juan Pablo Gallo

Submitted: June 20, 2017; Reviewed: July 12, 2017;

Accepted: November 17, 2017; Published on line: January 24, 2018. 
94 THERYA Vol. 9 (1):85-93 